\title{
ABNORMALITAS INTERPRETASI ELEKTROKARDIOGRAM MENURUT GAMBARAN NEUROIMAGING PADA STROKE HEMORAGIK
}

\author{
ELECTROCARDIOGRAM INTERPRETATION ABNORMALITIES ACCORDING TO \\ NEUROIMAGING IN HEMORRHAGIC STROKE
}

Dedi Sutia, * Syarif Indra, * Hendra Permana, * Andi Fadilah Yusran Putri, * Ribka Ankashima Sembiring*

\section{ABSTRACT}

Intoduction: Stroke is the third leading cause of death in the world (about $30 \%$ of cases of stroke are hemorrhagic). Cardiovascular disease has correlation to stroke, as risk factor and complication leading to mortality.

Aim: To describe electrocardiogram (ECG) interpretation abnormalities in acute hemorrhagic stroke patients.

Methods: This retrospective descriptive study evaluated the archive data of acute hemorrhagic stroke patients neurology ward General Hospital of Dr. M. Djamil Padang who according to inclusion and exclusion criteria since $1^{\text {st }}$ February to $30^{\text {th }}$ September 2018. The samples were an electrocardiography of acute hemorrhagic stroke patients. Data were analyzed by univariate analysis using statistical package for the social science (SPSS) software 23.

Results: This study administered 81 subjects; 34 subjects (41.98\%) were male and 47 subjects (58.02\%) were female. The highest age group was 61-70 years old (29.63\%). Most common risk factor was hypertension (66.68\%). There were 40 intracerebral hemorrhage (ICH) subjects (49.38\%) and 7 subarachnoid hemorrhage (SAH) subjects (11.11\%) who had ECG interpretation abnormality. Both groups had left ventricle hypertrophy (LVH) as the most common ECG interpretation abnormality (ICH: 40.76\%, SAH: 3.73\%). The only one of ICH with secondary SAH subject had ECG interpretation abnormality.

Discussion: Abnormal electrocardiogram interpretation were more common than normal electrocardiogram interpretation in acute hemorrhagic stroke subjects. Left ventricle hypertrophy (LVH) is the most common ECG interpretation abnormality in acute hemorrhagic stroke subjects.

Keywords: ECG abnormalities, hemorrhagic stroke, intracerebral hemorrhage, subarachnoid hemorrhage

\section{ABSTRAK}

Pendahuluan: Stroke adalah penyebab kematian ketiga terbanyak di dunia (sekitar 30\% kasus stroke adalah tipe stroke hemoragik). Masalah kardiovaskular berhubungan erat dengan stroke, sebagai faktor risiko dan komplikasi yang mengakibatkan mortalitas.

Tujuan: Penelitian ini mendeskripsikan temuan abnormalitas interpretasi elektrokardiogram (EKG) menurut gambaran neuroimaging pada pasien stroke hemoragik akut.

Metode: Penelitian deskriptif retrospektif ini mengevaluasi arsip data pasien stroke hemoragik akut di ruangan rawat inap neurologi ruangan rawat inap neurologi Rumah Sakit Umum Pusat Dr. M. Djamil, Padang yang sesuai dengan kriteria inklusi dan eksklusi sejak 1 Februari hingga 30 September 2018. Sampel penelitian adalah gambaran EKG pasien stroke hemoragik akut. Data dianalisis dengan analisis univariat menggunakan software statistical package for the social science (SPSS) 23.

Hasil: Pada penelitian ini didapatkan 81 subjek; 34 subjek (41,98\%) adalah laki-laki dan 47 subjek (58,02\%) adalah perempuan. Kelompok usia subjek terbanyak adalah kelompok usia 61-70 tahun $(29,63 \%)$. Faktor risiko terbanyak adalah hipertensi (66,68\%). Ada 40 subjek perdarahan intraserebral (PIS) (49,38\%) dan 7 subjek perdarahan subaraknoid (PSA) $(11,11 \%)$ yang memiliki abnormalitas interpretasi EKG. Kedua kelompok subjek memiliki left ventricle hypertrophy (LVH) sebagai abnormalitas interpretasi EKG terbanyak (PIS:40,76\%, PSA: 3,73\%) Ada 1 subjek PIS dengan PSA sekunder $(1,23 \%)$ dan subjek tersebut memiliki abnormalitas interpretasi EKG. Ada 14 subjek yang memiliki LVH sebagai abnormalitas interpretasi EKG dari 30,90\% yang memiliki perdarahan stroke di kapsula interna (lokasi perdarahan terbanyak). Jumlah subjek dengan interpretasi EKG normal terbanyak adalah subjek dengan perdarahan di talamus.

Diskusi: Left ventricle hypertrophy $(\mathrm{LVH})$ adalah temuan abnormalitas interpretasi EKG terbanyak yang ditemukan pada subjek perdarahan stroke di kapsula interna (lokasi perdarahan terbanyak). Jumlah subjek dengan interpretasi EKG normal terbanyak adalah subjek dengan perdarahan di talamus.

Kata kunci: Abnormalitas EKG, perdarahan intraserebral, perdarahan subarakhnoid, stroke hemoragik

*SMF Neurologi FK Universitas Andalas/RSUP Dr. M. Djamil, Padang. Korespondensi: dr.dedisutia@gmail.com. 


\section{PENDAHULUAN}

Abnormalitas gambaran elektrokardiogram pada stroke akut telah banyak dilaporkan sejak tahun 1947, terutama pada kejadian stroke iskemik akut dan pada perdarahan subaraknoid. Temuan abnormalitas elektrokardiogram (EKG) terumata terdiri dari aritmia, abnormalitas konduksi ataupun repolarisasi seperti gambaran elevasi maupun depresi segmen ST. Perubahan EKG tersebut terkadang mencerminkan penyebab dari stroke (kardioemboli serebri pada pasien dengan atrial fibrilasi), namun seringkali abnormalitas ini terjadi sebagai konsekuensi langsung ataupun merupakan sebuah manifestasi dari gangguan kardiak yang telah ada sebelumnya. ${ }^{1-3}$

Masalah kardiovaskular berhubungan erat dengan stroke, sebagai faktor risiko dan komplikasi yang mengakibatkan mortalitas. Faktor risiko stroke terbanyak di Indonesia adalah hipertensi (73,9\%). Hipertensi yang tidak terkontrol akan menyebabkan penyakit kardiovaskular, seperti left ventricle hypertrophy (LVH). Berbagai komplikasi dapat terjadi setelah serangan stroke, seperti komplikasi kardiovaskular. ${ }^{4}$ Lesi pada susunan saraf pusatpun dapat menyebabkan perubahan gambaran EKG, aritmia jantung dan gangguan refleks kardiovaskular. ${ }^{5-6}$ Guideline penanganan stroke secara umum merekomendasikan pemeriksaan EKG pada pasien stroke akut, dimana dalam praktek klinis sangatlah penting untuk membedakan abnormalitas EKG yang terjadi merupakan konsekuensi langsung akibat stroke ataupun merupakan abnormalitas akibat kerusakan miokard yang terjadi bersamaan. ${ }^{7}$

Pasien dengan stroke hemoragik juga dapat mengalami abormalitas EKG pada fase akut, namun fenomena ini masih sangat jarang dievaluasi secara sistematis pada pasien dengan perdarahan intraserebral intraparenkimal. ${ }^{2}$ Sebagian besar data hanya didapatkan dari beberapa laporan kasus. Dengan demikinan, peneliti tertarik untuk mendeskripsikan temuan abnormalitas interpretasi EKG pada pasien stroke hemoragik akut (awitan kurang dari 72 jam).

\section{METODE}

Desain penelitian ini adalah studi deskriptif retrospektif. Data pasien stroke hemoragik akut yang dirawat inap di RSUP Dr. M. Djamil, Padang selama periode 1 Februari sampai dengan 30 September 2018 dievaluasi pada penelitian ini. Kritera inklusi adalah pasien rawatan yang didiagnosis sebagai stroke hemoragik akut berdasarkan data hasil anamnesis, pemeriksaan fisik, pemeriksaan neurologi, algoritma stroke Gajah Mada serta pemeriksaan CT scan kepala yang tertera didalam rekam medis dengan onset kurang dari 72 jam, serta memiliki hasil pemeriksaan elektrokardiografi (EKG). Kriteria eksklusi adalah pasien dengan data tidak lengkap (tidak ada data gambaran EKG ataupun CT scan kepala tanpa kontras). Analisis data dilakukan secara deskriptif menggunakan software statistical package for the social science (SPSS) 23.

\section{HASIL}

Tabel 1 menujukkan bahwa mayoritas subjek berusia antara 61-70 tahun (29,63\%) dan memiliki faktor risiko hipertensi $(66,68 \%)$.

Tabel 1. Distribusi Karakteristik Subjek $(\mathrm{n}=\mathbf{8 1})$

\begin{tabular}{lc}
\hline \multicolumn{1}{c}{ Karakteristik } & $\mathbf{n}(\mathbf{\%})$ \\
\hline Jenis Kelamin & \\
- Laki-laki & $34(41,98)$ \\
- Perempuan & $47(58,02)$ \\
Usia & \\
- $31-40$ tahun & $1(1,23)$ \\
- $41-50$ tahun & $16(19,75)$ \\
- $51-60$ tahun & $21(25,93)$ \\
- $61-70$ tahun & $24(29,63)$ \\
- $71-80$ tahun & $12(14,81)$ \\
- $81-90$ tahun & $7(8,65)$ \\
Faktor Risiko & \\
- Tidak ada & $16(19,75)$ \\
- Diabetes melitus & $1(1,23)$ \\
- Hipertensi & $54(66,68)$ \\
- Hipertensi dan diabetes melitus & $4(4,94)$ \\
- Hipertensi dan penyakit jantung & $5(6,17)$ \\
- Hipertensi, penyakit jantung, dan diabetes & $1(1,23)$ \\
\hline
\end{tabular}

Berdasarkan tabel 2, abnormalitas interpretasi EKG ditemukan pada 48 subjek $(59,26 \%)$, dengan rincian 40 subjek PIS, 7 subjek PSA, dan 1 subjek PIS dengan PSA sekunder. Di antara jenis abnormalitas yang didapat, LVH merupakan kelainan yang paling sering terjadi, dengan angka kejadian pada masingmasing tipe sebesar 40,76\% (PIS), 3,73\% (PSA), dan $1,23 \%$ (PIS dengan PSA sekunder). 
Tabel 2. Distribusi Interpretasi EKG Berdasarkan Tipe Stroke Hemoragik Akut (n=81)

\begin{tabular}{lrr}
\hline \multicolumn{1}{c}{ Tipe } & \multicolumn{1}{c}{ Interpretasi EKG $(\mathbf{\%})$} & $28(34,57)$ \\
\hline PIS & Normal & $33(40,76)$ \\
& Abnormal & $2(2,47)$ \\
& $\bullet$ LVH & $1(1,23)$ \\
& $\bullet$ MCI & $1(1,23)$ \\
& $\bullet$ Sinus takikardi & $1(1,23)$ \\
& $\bullet$ AF NVR dan LVH & $1(1,23)$ \\
& $\bullet$ AF RVR dan old MCI & $1(1,23)$ \\
PSA & $\bullet$ LVH dan STEMI & $5(6,17)$ \\
& $\bullet$ LVH, MCI, sinus bradikardi & $1(1,23)$ \\
& Normal & $3(3,73)$ \\
& Abnormal & $1(1,23)$ \\
& $\bullet$ AF RVR & $1(1,23)$ \\
& $\bullet$ LVH & $1(1,23)$ \\
& $\bullet$ MCI & 0
\end{tabular}
ventricle hypertrophy, MCI: myocardial infarction, NSTEMI: non-ST segment elevation myocardial infarction, old MCI: old myocardial infarction, PIS: perdarahan intraserebral, PSA: perdarahan subarakhnoid, STEMI: ST segment elevation myocardial infarction.

Tabel 3 menunjukkan lokasi perdarahan stroke terbanyak di kapsula interna, yaitu 25 subjek (30,90\%). Dalam kelompok tersebut, abnormalitas interpretasi EKG yang paling sering didapat adalah LVH (16,11\%). Di lain pihak, talamus adalah lokasi perdarahan dengan proporsi jumlah subjek dengan interpretasi EKG normal terbanyak $(13,58 \%)$ di antara lokasi-lokasi yang lain.

\section{PEMBAHASAN}

Pada penelitian ini didapatkan 81 subjek. Terdapat 47 subjek $(58,02 \%)$ perempuan dan 34 subjek (41,98\%) laki-laki. Temuan ini berbeda dengan penelitian Wang $\mathrm{R}$ dkk namun sesuai dengan penelitian Patrizia F dkk. Dari 141 subjek yang diteliti Wang R dkk, 69 subjek adalah laki-laki dan 55 subjek adalah perempuan. ${ }^{8}$ Patrizia F dkk menemukan 287 subjek perempuan (52\%) dari 552 subjek stroke. ${ }^{9}$ Jenis kelamin memengaruhi insiden dan fungsional luaran pada stroke. Roy-O'Reilly M dkk menemukan bahwa jenis kelamin memengaruhi insiden dan fungsional luaran stroke; meskipun insiden pada lakilaki lebih tinggi daripada perempuan di kelompok usia tertentu, wanita memiliki prevalensi stroke yang lebih tinggi daripada laki-laki di keseluruhan usia. Ini terjadi karena adanya usia harapan hidup perempuan yang lebih tinggi dan peningkatan risiko stroke seiring dengan pertambahan usia. ${ }^{10}$ Terdapat hubungan antara jenis kelamin dengan temuan abnormalitas pada EKG, seperti pada penelitian yang dilakukan oleh Adeoye dkk sebelumnya, didapatkan stroke terjadi pada perempuan dengan usia yang lebih tua bila dibandingkan dengan laki-laki disertai dengan tingginya frekuensi takikardi, atrial fibrilasi, dan ventrikular takikardi. Gambaran EKG LVH juga ditemukan lebih sering pada perempuan. Sementara itu, laki-laki lebih cenderung memiliki nilai tekanan darah diastolik rata-rata yang lebih tinggi. ${ }^{6}$

Penatalaksanaan stroke hemoragik akut sangatlah bergantung kepada pengenalan akan risiko morbiditas dan mortalitasnya, dimana hipertensi merupakan salah satu faktor yang sangat berpengaruh terhadap luaran klinis pasien nantinya. Peningkatan tekanan darah dapat meningkatkan kecenderungan terjadinya perdarahan pada stoke hemoragik. ${ }^{11}$ Pada penelitian ini didapatkan faktor risiko stroke hemoragik terbanyak adalah hipertensi $(66,68 \%)$. Hal ini sesuai dengan penelitian yang dilakukan oleh Adeoye dkk, dimana ditemukan kejadian peningkatan parameter tekanan darah rerata pada pasien dengan stroke hemoragik bila dibandingkan dengan stroke iskemik. Selain itu, kejadian stroke di Indonesia mempunyai tiga faktor risiko utama terbanyak, yaitu hipertensi 
Tabel 3. Distribusi Interpretasi EKG Berdasarkan Lokasi Perdarahan (n=81)

\begin{tabular}{|c|c|c|}
\hline Lokasi Perdarahan & Interpretasi EKG & n (\%) \\
\hline Ganglia Basalis & $\begin{array}{l}\text { Normal } \\
\text { Abnormal } \\
\text { - LVH } \\
\text { - } \text { AF NVR dan LVH }\end{array}$ & $\begin{array}{l}6(7,41) \\
6(7,41) \\
1(1,23)\end{array}$ \\
\hline Serebelum & $\begin{array}{l}\text { Normal } \\
\text { Abnormal } \\
\text { - LVH }\end{array}$ & $\begin{array}{l}2(2,46) \\
2(2,46)\end{array}$ \\
\hline Mesensefalon & $\begin{array}{l}\text { Normal } \\
\text { Abnormal } \\
\text { - LVH }\end{array}$ & $\begin{array}{l}1(1,23) \\
1(1,23)\end{array}$ \\
\hline Pons & $\begin{array}{l}\text { Normal } \\
\text { Abnormal } \\
\text { - LVH } \\
\text { - } \text { LVH dan STEMI }\end{array}$ & $\begin{array}{l}3(3,72) \\
2(2,46) \\
1(1,23)\end{array}$ \\
\hline Kapsula Interna & $\begin{array}{l}\text { Normal } \\
\text { Abnormal } \\
\text { - AF RVR } \\
\text { - } \text { LVH } \\
\text { - } \text { MCI } \\
\text { - AF RVR dan old MCI } \\
\text { - LVH dan NSTEMI } \\
\text { - } \text { LVH, MCI dan sinus bradikardi }\end{array}$ & $\begin{array}{c}7(8,64) \\
1(1,23) \\
14(16,11) \\
1(1,23) \\
1(1,23) \\
1(1,23) \\
1(1,23)\end{array}$ \\
\hline Korteks Serebri & $\begin{array}{l}\text { Normal } \\
\text { Abnormal } \\
\text { - LVH } \\
\text { - MCI }\end{array}$ & $\begin{array}{l}3(3,72) \\
4(4,92) \\
1(1,23)\end{array}$ \\
\hline Talamus & $\begin{array}{l}\text { Normal } \\
\text { Abnormal } \\
\text { - } \text { LVH } \\
\text { - } \text { MCI } \\
\text { - Sinus takikardi } \\
\text { - } \text { LVH dan old MCI }\end{array}$ & $\begin{array}{l}11(13,58) \\
8(11,12) \\
1(1,23) \\
1(1,23) \\
1(1,23)\end{array}$ \\
\hline
\end{tabular}

AF NVR: atrial fibrilasi normal ventricle response, AF RVR: atrial fibrilasi rapid ventricle response, EKG: elektrokardiogram, LVH: left ventricle hypertrophy, MCI: myocardial infarction, NSTEMI: non-ST segment elevation myocardial infarction, old MCI: old myocardial infarction, STEMI: ST segment elevation myocardial infarction.

(73,9\%), diabetes melitus (17,3\%), dan perokok (20,4\%) Peningkatan tekanan darah yang terjadi memiliki patofisiologi yang belum terlalu jelas, apakah merupakan sebuah respons hipertensif akut ataupun merupakan sebuah kondisi tekanan darah kronis yang tidak terkontrol sebelumnya. Pemahaman ini juga sesuai dengan tingginya kecendrungan temuan abnormalitas gambaran EKG pada penelitian ini $(59,26 \%)$, dimana mekanisme yang jelas masih belum dipahami sepenuhnya. ${ }^{6,12-13}$

Mekanisme patologis bagaimana sebuah kondisi stroke akut dapat menyebabkan berbagai macam abnormalitas pada gambaran EKG masih belum pasti. Namun, diketahui bahwa disregulasi otonom terkait aktivitas yang berlebihan dari tonus simpatetik yang menyebabkan peningkatan katekolamin. ${ }^{14}$ Pada penelitian ini, didapatkan abnormalitas EKG terbanyak pada pasien dengan stroke hemoragik akut ialah gambaran LVH. Hal ini sesuai dengan penelitian yang dilakukan oleh Adeoye dkk, yang menemukan bahwa gambaran LVH ditemukan lebih banyak pada pasien dengan stroke hemoragik akut, sementara pada pasien dengan stroke infark akut, atrial fibrilasi lebih banyak ditemukan. Gambaran LVH pada pemeriksaan EKG menggambarkan sebuah tanda penting terjadinya penyakit organ target akibat hipertensi. ${ }^{6,15}$ Sementara itu, hasil penelitian ini berbeda dengan temuan penelitian yang dilakukan 
oleh Cut Ariana dkk. Cut Aria Arina meneliti abnormalitas gambaran EKG pada pasien stroke dengan cara membandingkan dengan subjek kontrol. Ada 21 subjek stroke $(77,8 \%)$ memiliki abnormalitas gambaran EKG; stroke iskemik sebanyak 13 subjek, perdarahan intraserebral sebanyak 6 subjek, perdarahan subaraknoid sebanyak 2 subjek. Namun ada perbedaan untuk hasil gambaran yang ditemukan. Cut Aria Arina menemukan abnormalitas gambaran EKG yang terbanyak pada PIS adalah gangguan ritme $(37,5 \%)$ sedangkan pada PSA adalah T inversi dan ST depresi (masing-masing 33,3\%). ${ }^{16}$

Penelitian yang menghubungkan antara abnormalitas gambaran EKG dengan lokasi lesi otak telah dilakukan dalam beberapa penelitian sebelumnya, namun hal yang didapatkan selalu berbeda-beda. Stimulasi langsung dari berbagai area di sistem saraf pusat diketahui dapat menyebabkan perubahan pada gambaran EKG. Pada penelitian yang dilakukan oleh Crop dan Manning, Shuster dan Hunt dkk ditemukan bahwa tidak terdapatnya hubungan antara perubahan gambaran EKG dengan lokasi dari aneurisma otak. ${ }^{17-18}$ Sementara itu, pada penelitian yang dilakukan oleh Yamour ditemukan hubungan antara abnormalitas EKG dengan lokasi lesi, dimana terdapatnya hubungan antara aritmia dan abnormalitas gelombang $\mathrm{T}$ dengan perdarahan pada sirkulasi anterior pada pasien stroke hemoragik. ${ }^{19}$ Temuan utama pada penelitian ini ialah banyaknya jumlah pasien dengan gambaran EKG abnormal dengan lokasi perdarahan dikapsula interna. Dengan demikian, berdasarkan berbagai observasi, sulit untuk membangun sebuah korelasi yang jelas antara lokasi gangguan intrakranial dengan gambaran abnormalitas EKG tertentu.

Pada penelitian kami, walaupun merupakan sebuah penelitian retrospektif, penelitian ini menambah pengetahuan dan pemahaman akan kegunaan pemeriksaan EKG dalam kondisi stroke hemoragik akut. Populasi penelitian kami juga mewakili mayoritas pasien stroke hemoragik akut yang dirawat dirumah sakit pusat kami sebagai satunya-satunya rumah sakit pelayanan tersier yang ada di provinsi Sumatera Barat.

\section{KESIMPULAN}

Penelitian ini menunjukkan bahwa left ventricle hypertrophy (LVH) adalah temuan abnormalitas interpretasi EKG terbanyak yang ditemukan pada subjek perdarahan stroke di kapsula interna (lokasi perdarahan terbanyak). Temuan ini diduga berkaitan dengan faktor risiko hipertensi pada subjek penelitian. Jumlah subjek dengan interpretasi EKG normal terbanyak adalah subjek dengan perdarahan di talamus.

\section{DAFTAR PUSTAKA}

1. Khechinashvili G, Asplund K. Electrocardiographic changes in patients with acute stroke: A systematic review. Cerebrovasc Dis. 2002;14:67-76.

2. Bree M, Ross Y, Bilt I, Wilde A, Sprengers M, dkk. Prevalence and characterization of ECG abnormalities after intracerebral hemorrhage. Neurocrit Care [serial online]. 2010 (diunduh 12 Desember 2019);12:50-5. Tersedia dari: Neurocrit Care.

3. Liu Q, Ding $Y$, Yan $P$, Zhang JH, Lei $H$. Electrocardiographic abnormalities in patients with intracerebral hemorrhage. Acta Neurochirurgica Supplementum [serial online]. 2011 (diunduh 15 Juni 2019);111:353-6. Tersedia dari: Acta Neurochirurgica Supplementum.

4. Kenmogne-Domning G, Kamtchum-Tatuene J, Noumegni S, Fokoua-Dongmo C, Zafack J, dkk. Cardiac complications after stroke: protocol for a systematic review and meta-analysis. BMJ Open [serial online]. 2018 (diunduh 15 Januari 2019);8(5):e021416. Tersedia dari: BMJ Open.

5. Kaya A, Arslan Y, Özdoğan Ö, Tokuçoğlu F, Şener $\mathrm{U}$, dkk. Electrocardiographic changes and their prognostic effect in patients with acute ischemic stroke without cardiac etiology. Turk J Neurol [serial online]. 2018 (diunduh 15 Juni 2019);24(2):137-42. Tersedia dari: Turk J Neurol.

6. Adeoye A, Ogah O, Ovbiagele B, Akinyemi R, Shidali V, dkk. Prevalence and prognostic features of ECG abnormalities in acute stroke. Glob Heart [serial online]. 2017 (diunduh 12 Desember 2018);12(2):99105. Tersedia dari: Glob Heart.

7. Powers W, Rabinstein A, Ackerson T, Adeoye $\mathrm{O}$, Bambakidis N, dkk. Guidelines for the early management of patients with acute ischemic stroke: 2019 update to the 2018 guidelines for the early management of acute ischemic stroke: a guideline for healthcare professionals from the American heart association/American stroke association. AHA Journals [serial online]. 2019 (diunduh 15 September 2019);50(12). Tersedia dari: AHA Journals.

8. Wang R, Wei Y, Teng J. Levels of plasma n-terminal pro-brain natriuretic peptide and d-dimer on the 
prognosis of patients with acute cerebral infarction. Pak J Med Sci [serial online]. 2018 (diunduh 15 Januari 2019);34(4). Tersedia dari: Pak J Med Sci.

9. Patrizia F, Guglielmo C, Antonio C, Giulia C, Maria DG, dkk. Cardiac biomarkers in acute stroke. Academia J Stroke [serial online]. 2019 (diunduh 15 September 2019);1:002. Tersedia dari: Academia J Stroke.

10. Roy-O'Reilly M, Mccullough LD. Age and sex are critical factors in ischemic stroke pathology. Endocrinology [serial online]. 2018 (diunduh 15 Januari 2019);159(8):3120-31. Tersedia dari: Endocrinology.

11. Qureshi A, Ezzeddine MA, Nasar A, Suri MFK, Kirmani JF, Hussein HM, dkk. Prevalence of elevated blood pressure in 563704 adult patients with stroke presenting to the ED in the United States. Am J Emerg Med. 2007;25(1):32-9.

12. Ghani L, Mihardja LK, Delima. Faktor risiko dominan penderita stroke di indonesia. Buletin Penelitian Kesehatan [serial online]. 2016 (diunduh 15 Januari 2019);44(1):49-58. Tersedia dari: Buletin Penelitian Kesehatan.
13. The George Institute for Global Health. Reducing the burden of cardiovascular disease in Indonesia; 2019.

14. Samuels MA. The brain-heart connection. Circulation. 2007;116(1):77-84.

15. Zhao Y, Huang X, Zhang PP, Bao H, Yu Y, Zhao M, dkk. Electrocardiographoc-left ventricular hypertrophy and incident stroke among Chinese hypertensive adults. J Hum Hypertens. 2019;34:286-92.

16. Arina C. Hubungan tipe stroke dengan abnormalitas gambaran elektrokardiografi [disertasi]. Medan: Universitas Sumatera Utara; 2019.

17. Togha M, Sharifpour A, Ashraf H, Moghadam M, Sahraian M. Electrocardiographic abnormalities in acute cerebrovascular events in patients with/withour cardiovascular disease. Ann Indian Acad Neurol. 2013;16(1):66-71.

18. Hunt D, McRae Z, Zapf P. Electricardiographic and serum enzyme changes in subarachnoid hemorrhage. Am Heart J. 1969;77:479-88.

19. Yamour BJ, Sridharan MR, Rice JF, Flowers NC. Electrocardiographic changes in cerebrovasculr hemorrhage. Am Heart J. 1980;99:294-300. 